\title{
"I Know I Am, But What Are You?": Public Perceptions of Unions, Members and Joining Intentions
}

\author{
Ray Gibney ${ }^{1, *}$, Marick Masters ${ }^{2}$, Ozge Aybat ${ }^{1}$ and Thomas Amlie ${ }^{1}$ \\ 1 School of Business Administration, The Pennsylvania State University at Harrisburg, \\ Middletown, PA 17057, USA; oua3@psu.edu (O.A.); tta2@psu.edu (T.A.) \\ 2 School of Business, Wayne State University, Detroit, MI 48201, USA; marickm@wayne.edu \\ * Correspondence: rfg14@psu.edu; Tel.: +1-(717)-948-6149
}

Received: 23 July 2018; Accepted: 28 August 2018; Published: 31 August 2018

\begin{abstract}
Respondent's perceptions of demographic, social and behavioral characteristics of union members were analyzed in comparison to the statistical data regarding union members. Respondents also provided perceptions regarding unions themselves as well as future joining intentions. Overall, respondents accurately identified some characteristics of union members and were incorrect on others. General union image was poor as well as future joining intentions. The results of this analysis suggest that union density declines in the private sector will continue.
\end{abstract}

Keywords: social identity; social categorization; union joining intentions

\author{
"Perception is reality" - L. Atwater \\ "We act on what we perceive to be real and true. That's functional reality but often, it's not true reality." \\ -R. Campbell
}

Unions' raison d'etre is the protection of employee rights to fair treatment. However, although there should be a balance between individual rights, group rights and societal goods, occasionally, these are at loggerheads. For example, in 2014, heroin and related usage paraphernalia were found in a teacher's bathroom at an elementary school and the police were notified. An investigation ensued and narrowed the suspects to a small group of unionized teachers and aides. As the probe continued, the union stepped in and ground the investigation to a halt. Many parents, as well as much of the community, were outraged. Thus, in the protection of members' rights, the union may also be perceived to be detrimental to society, children and other workers.

Other cases often negatively influence the perceptions of union members as well. In these instances, members seemingly act alone in a miscreant manner. Ed Sweeney was convicted of arson, among other charges, related to burning down of a Quaker (avowed pacifists) meeting house because union members were not hired to build it. In a similar vein, Joseph Dougherty, of the Ironworkers Union, was sentenced to nearly 20 years in prison on an array of charges. The FBI has spent years investigating alleged criminal activity by another labor union leader, John Dougherty of the Electricians union. FBI wire taps connect John Dougherty to high ranking local politicians. As with many other criminals, alleged or convicted, a social stigma is attached and individuals attempt to disassociate with these people. Given that union members frequently refer to one another as brother or sister, one is naturally inclined to ask, do you want to freely associate with these individuals? Granted these are the actions of a limited group of union members, but the possibility does arise that this will become the perceptions associated with the union or its members. 
On the other hand, it is also quite possible that more positive acts by union members are the actions that form the basis of the stereotypes of union members. In 2017, a series of hurricanes battered the southern United States. Homes were destroyed and many residents needed assistance rebuilding. Unions from across the United States are contributing money, goods and time to help the victims of the hurricane ravaged areas. The actions of these union members could create a positive image of the union and its members, thereby increasing the desirability of affiliation with these members.

In addition to the actions and behaviors of the union members, general perceptions regarding various demographic and societal statuses influence the desirability of union membership. The adage regarding flocking birds ("Birds of feather, flock together") pertains to demographic, social and behavioral criteria. Social proximity (Festinger 1954), social identity (Tajfel 1972), social attractiveness (Hogg and Hains 1996) and social categorization (Hogg and Terry 2000) have traditionally been used to understand group membership formation and desirability. At the heart of these theories are beliefs regarding members of groups and the groups themselves.

Non-union members who see themselves as having similar characteristics as union members may be more willing to associate with them and possibly join unions. While surface level characteristics are known to bring individuals together, more deeply held characteristics (e.g., political ideology) are also associated with group cohesiveness (Hogg and Abrams 2007). People are attracted to and join groups with similarly held values and characteristics (Schneider and Smith 2004; Butler et al. 2014). However, perceptions are wrought with cognitive errors and biases, and outgroup members often hold incorrect perceptions of the meaning of being a group member.

This study compares perceptions of union members to the actual data on union members to determine if potential union members correctly perceive the "union member". Respondents' perceptions of the union itself are also discussed as well as their behavioral intentions regarding future union joining. Finally, practical implications and suggestions for union leadership are offered.

\section{Theoretical Background}

There is a long and undisputed decline in union density rates in the United States. Union density peaked in the 1950s and has been steadily declining since the heyday. Many different reasons have been offered to explain the decline. One typology focuses on union image (Youngblood et al. 1984). More recently, others have begun to note that the union image is based upon the actions of the members (Cornwell and Harrison 2004). Another possible explanation is individuals' less involvement in groups and civic engagement (Putnam 2001). This decline in voluntary associations such as unions in America for decades may have been exacerbated with Millennials (Cates 2014). The topics of decline in union density, perceptions regarding labor unions, perceptions about union members, and finally union joining intentions are briefly reviewed next.

\subsection{Decline in Union Density}

Unions reached their pinnacle of union density in the 1950s and membership in the 1970s (Rosenfeld 2014). While overall union density has been on a near constant decline over the last six decades, this has not been uniform in all sectors. Public sector union density has generally fluctuated around one-third, but private sector has reached 1930s levels of union density (Rosenfeld 2014).

Various reasons have been offered for the overall decline in union density including changing demographics and work environments, substitution effects and the actions of the union themselves (Youngblood et al. 1984; Rosenfeld 2014; Masters et al. 2006). The demographic and work environment argument suggests that, as the workforce and the nature of work have changed, individuals and industries that were predisposed to joining a union now comprise a far smaller percentage of the workforce. For example, African Americans, college graduates, and white-collar employees are less desirous of union representation, but are an increasing percentage of the workforce. Therefore, as these populations increase as a percentage of the workforce, union density declines. The results of the current study suggest that this may not be accurate. 
The substitution argument is that unions have been so effective in their support of workers that government legislation and regulation have been incorporated into law and are now required of all companies. Because individuals can get the benefits associated with unionism without the associated costs such as dues and fees, the government has effectively substituted itself for unions. This is closely aligned with the idea of political unionism in which unions work to support the election of political candidates who are supportive of labor's agenda (Masters et al. 2006).

The government substitution effect is amplified by the human resource substitution effect through mimetic isomorphism. Given that there is no appreciable increase in productivity, decreased profitability to companies and detrimental economic effects to the economy writ large (Doucouliagos and Laroche 2003; Hirsch 2004), management attempts to provide benefits that would be gained through unionization without the associated cost to employees and employers alike. Recently, unions have been welcomed into companies with a union acceptance strategy, but lose the election even when supported by the company and union (Leef 2015).

The actions of the unions argument were at the heart of the split of the Change-To-Win (CTW) from the AFL-CIO (Masters et al. 2006). A contrast to political unionism is the concept of business unionism. Business unionism is best conceptualized as the traditional union activities such as organizing campaigns, negotiations and other bread and butter activities of the union. The CTW leadership argued that the leadership of the AFL-CIO had lost sight of business activities and was too focused on political unionism. At the Federal level, unions were instrumental in the elections of Presidents Clinton and Obama. There has been a long history of unions supporting and endorsing Democratic candidates. Roughly, $40 \%$ of Americans are registered Democrats. By strictly endorsing Democrats, the union may alienate up to $60 \%$ of the country who are not registered Democrats. If potential members incorporate political affiliations and ideology (e.g., Moderate independent), they may be less inclined to see an overlap of personal identity and union identity which would reduce union joining intentions.

\subsection{Perceptions of Union}

The actions of the unions must be taken in a larger context. The behavior of unions creates perceptions of the unions which are highly predictive of union certification election results (Youngblood et al. 1984; Barling et al. 1991). This view (Medoff 1987) argues that individuals become aware of the actions of the union through experience, friends, media, etc. and form an overall perception of the union. The union image is compared to the individual's self-perception which influences voting behavior.

Overall, as the approval rate of unions has declined so has union density (Medoff 1987). More recently, scholars have begun to disentangle the beliefs regarding unions as a whole from beliefs regarding specific unions (Park et al. 2006). The idea is that individual unions may have a better public image than all unions combined such as in "I disapprove of unions but mine is great" viewpoint. Even though divergent general and specific beliefs coexist, Park et al. (2006) found that general beliefs are three times stronger than specific beliefs. Interestingly, general attitudes toward labor influence attitudes regarding specific unions but not vice versa. Overall, all labor must work together to create a positive image of labor and individual unions must work to maintain their own positive image because both specific and general attitudes toward unions are significantly related to union voting behaviors.

The perceptions are often formed long before union organizing campaigns. Barling and colleagues (Barling et al. 1991) noted that "employees' voting decisions were consistently predicted by their union attitudes prior to the start of the campaign" (p. 725). Similarly, Park and colleagues (Park et al. 2006) stated that "general beliefs are formed at relatively early stage of life and are more stable than specific beliefs. Hence, it may be more difficult for unions to affect general beliefs during a union-organizing drive" (p. 285). Views of work and work context are quite different between generations (Twenge et al. 2012). Therefore, understanding the current generations' (Millennials) general attitude toward unions is of the utmost importance if unions are going to rebound. 


\subsection{Perceptions of Union Members}

According to social categorization theory and social attractiveness theory, not only do individuals compare self-identity to organizational/institutional identity, but also to perceptions of the stereotypical/prototypical union member. Understanding the perceptions regarding union members and their influence on organizations and employees in research has largely been ignored (Barling et al. 1992). Little has been written regarding how non-union members perceive union members and how this will influence the union joining intentions.

This is striking given that union image is predicated not only on the actions of the union leadership, but also the actions of the membership. In addition, the image of the union member, demographically, socially and behaviorally, forms the basis of stereotype/prototype formation. Given the vital importance, it is astounding that there is a lack of research regarding the nonunion members' perception of union members. In addition to being significant for union joining intentions of non-union members, union member perceptions of the depersonalized member could also be associated with disidentification (Elsbach and Bhattacharya 2001). Research indicates that union member's identification with the union will have ramifications for helping the union and other members (Gibney et al. 2012).

Cornwell and Harrison (2004) suggested union/organizational embeddedness as a method to overcome union density declines. They argue that union members should become involved in societal organizations, associations and clubs such as youth sports, the PTA or the Masons. Through these social, religious and sports groups, nonunion members can interact with members and develop a personalized relationship. Generally, individuals see in-group members in a more positive light (Tajfel 1972). Therefore, this similar-to-me effect will aid in the development of a positive perception of union members and could slow if not reverse union density decline. Another area to create positive images of union members is through social media (Gibney et al. 2013).

\subsection{Union Joining Intentions}

Attitudes toward the union, and by default union joining intentions, are determined long before campaigns begin. General union attitude is a significant predictor of union success in union certification elections. In addition to interaction with members through clubs and organizations, familial and friendship relationships are critical to the formation of attitudes toward unions, and quite possibly union members (Barling et al. 1991). Barling and colleagues (Barling et al. 1991) found that parental participation and parental attitude toward the union played a large role in determining their children's attitudes toward the union. Another strong predictor of the union joining intention was the strength of socialist/communist ideology which is most likely instilled, in part, by parent's views. With declining union density, parental participation declines and so does exposure to union members.

Cornwell and Harrison (2004) organizational/institutional embeddedness solution may not be fruitful because Americans are "bowling alone" (Putnam 2001). Putnam (2001) found that civic engagement and social capital were largely declining over the last few decades because people are not joining groups whether it be the PTA, labor unions or church groups. However, different generations form different attitudes, and subsequently behaviors, regarding diverse topics from the nature of work to economic systems (Twenge et al. 2012). The Millennials have generally been considered the "us" generation, much more socially engaged and, for the most part, inclined toward socialism. These are all positive indicators for the revival of unions. For example, Marxist ideology has been shown to be a positive predictor of a more positive union image (Barling et al. 1991). Millennials have also not had much exposure to stereotypes of unions through either social media or the media to form given the low usage of social media by unions (Gibney et al. 2013).

Twenge and colleagues (Twenge et al. 2012) compared Millennials to other generations on a variety of attitudes and behaviors. Millennials' civic engagement did decline in comparison to Gen X, but at a slower rate. Millennials were also found to have far less concerns for others and empathy. Nevertheless, interestingly, they did perform more community service in high school and 
college than prior generations. Twenge et al. (2012) suggested that the increased community service may be due to requirements placed upon them by educational, social and religious organizations. For example, the National Honor Society and Catholic Church (as part of the sacrament of confirmation) require community service and many universities require recognized clubs to hold at least one community service event annually. Therefore, the increased community service may not be voluntary. However, Twenge et al. (2012) did not collect data regarding attitudes toward unions, members or joining intentions as part of their study. Therefore, the current research fills that gap as explained in the next section.

\section{Sample and Method}

\subsection{Sample}

Respondents were students currently enrolled in business degree programs at two large public universities in the northeastern United States. Students were targeted because of a recent ruling allowing graduate students to organize. One of the universities is currently undergoing an organizing campaign. Another reason targeting students is that a major employer in both areas are governmental agencies which have higher rates of union density. Unions have had difficulty in organizing white-collar workers (Bronfenbrenner 1998) who often form attitudes and beliefs regarding unions long before campaigns. The sample consisted of 306 business students enrolled in a diverse set of business courses such as organizational behavior, human resources, negotiations and marketing. Students were given a small monetary token of appreciation (\$1) or nominal extra-credit points (2) for completing the survey. The sample was 53\% male and 78\% Caucasian. The average age was approximately 23 years. Approximately 33\% identified themselves as belonging to the Democratic Party and 26\% stated that they ascribed to a liberal political ideology. In the United States, unions have a closer relationship with the Democratic Party than with the Republican Party (Dark 2000).

\subsection{Method}

A short introduction was provided to prime respondents with image development by using the term cheerleader. When they heard the term cheerleader, respondents commonly reported an image of a young, attractive and physically fit female. Participants were then asked to develop a mental image of a union member and respond to items describing the characteristics of this union member. The characteristics included demographic (gender, ethnicity, age, education, and socioeconomic status), work environment (blue vs. white collar, indoor or outdoor, industry, and occupation) and political views (party affiliation and leaning). Beyond capturing surface level demographic data regarding the respondent's image of the union member, additional items were collected using a 7-point Likert scale ranging from "Strongly Disagree" to "Strongly Agree". The additional items captured respondent's beliefs regarding union members' work habits and pay, union image, and union joining intentions. Participants also completed items about union worker characteristics and behaviors including being hardworking, complaining about work conditions and being overpaid. An additional item captured the extent to which the respondent had a negative image of union members and perceived overlap of characteristics with the respondent.

To assess participant's attitude toward the union, measures from the AFL-CIO's 1999 Labor Day Study administered by Peter D. Hart Research Associates were modified and adapted (www.aflcio.com). In the AFL-CIO's study, respondents were asked to choose between two sentences (one pro-union and one anti-union) on nine categories. One sentence from each of these nine forced choice questions was selected by flipping a coin. When the coin landed with heads facing upward, pro-union statements were selected. Responses were measured on a 7-point Likert Scale.

Union joining intentions focused on whether participants felt that they would vote for a union during a union certification election, voluntary join a union, and take a job if it required joining a union. Each joining intention was captured with a single item. Data were analyzed in reference to answers to 
the following questions: (1) What are the most frequently reported characteristics of a stereotypical union member? (2) Does the stereotypical/ prototypical union member exemplify the statistically average union member?

\section{Result}

\subsection{Image}

The most frequently described union member is a high-school educated, middle-class, white male between the ages of 36 and 45. Additionally, he works outdoors performing a blue-collar construction or maintenance job in a manufacturing industry. He is also a moderate Democrat. Respondents were likely to believe that the union member worked in either a production or construction occupation. Table 1 contains the percentage of responses in each category.

Table 1. Demographics of Imagined Union Member.

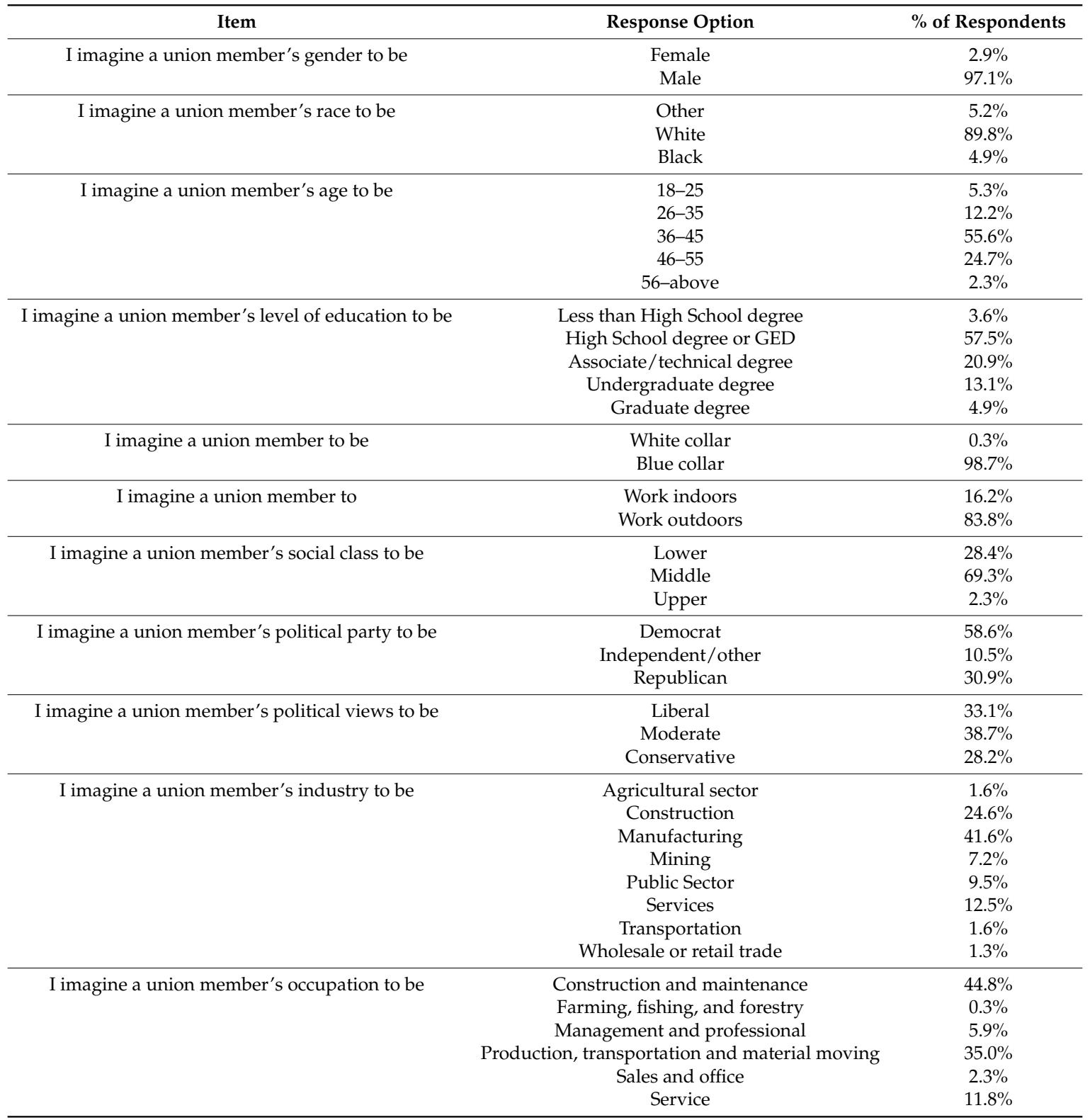




\subsection{Average Member}

To compare the survey responses to actual characteristics of the union workers, a statistical image of the average union worker was generated utilizing the Current Population Survey (CPS) data and the American National Election Studies (ANES). The CPS is a monthly survey conducted by the Bureau of the Census for the Bureau of Labor Statistics (BLS) and "is the primary source of information on the labor force characteristics of the U.S. population" (http:/ / www.bls.census.gov/cps/overmain.htm). Approximately 54,000 households are surveyed monthly (approximately 106,000 respondents) and an array of demographic information about labor force characteristics, including the union status of workers (i.e., do they belong to a union) are collected. Each year, the BLS reports on the state of union membership in the United States in an annual report (https://www.bls.gov/news.release/union2. $\mathrm{nr0.htm).} \mathrm{ANES} \mathrm{also} \mathrm{captures} \mathrm{union} \mathrm{data} \mathrm{on} \mathrm{political} \mathrm{affiliations,} \mathrm{ideologies} \mathrm{and} \mathrm{other} \mathrm{data} \mathrm{such} \mathrm{as}$ educational attainment and social status (http:/ / www.electionstudies.org/).

Table 2 shows the demographic breakdowns of the union and non-union workers in the reported annual data from the BLS and the election cycle data from the ANES. It reveals that the union sub-sample is slightly older and comprised of more males than the non-union group. While the union population is predominantly Caucasian, it is more diverse than the non-union subset. Interestingly, while the High School graduate is the largest group in both the union and non-union subsets, union members are much more likely to have earned a graduate degree than non-union members. Union members are also much more likely to belong to Democrat party and have a Liberal ideology than a Moderate or Conservative stance. Interestingly, union members are far less Conservative than non-union members.

Table 2. Characteristics of workforce.

\begin{tabular}{|c|c|c|c|c|}
\hline Variable & Classifications & Total & Union & Non-Union \\
\hline \multicolumn{5}{|l|}{ Age } \\
\hline & 16 to 24 years & $13.6 \%$ & $5.6 \%$ & $14.6 \%$ \\
\hline & 25 to 34 years & $23.3 \%$ & $20.1 \%$ & $23.7 \%$ \\
\hline & 35 to 44 years & $21.0 \%$ & $23.5 \%$ & $20.6 \%$ \\
\hline & 45 to 54 years & $21.2 \%$ & $26.4 \%$ & $20.5 \%$ \\
\hline & 55 to 64 years & $16.0 \%$ & $19.9 \%$ & $15.5 \%$ \\
\hline & 65 years and over & $4.9 \%$ & $4.4 \%$ & $5.0 \%$ \\
\hline \multicolumn{5}{|l|}{ Gender } \\
\hline & Male & $51.9 \%$ & $54.2 \%$ & $51.6 \%$ \\
\hline & Female & $48.1 \%$ & $45.8 \%$ & $48.4 \%$ \\
\hline \multicolumn{5}{|c|}{ Race and Hispanic or Latino Ethnicity } \\
\hline & White & $78.0 \%$ & $76.4 \%$ & $78.2 \%$ \\
\hline & Black or African American & $12.5 \%$ & $15.2 \%$ & $12.2 \%$ \\
\hline & Asian & $6.1 \%$ & $5.2 \%$ & $6.2 \%$ \\
\hline & Hispanic or Latino ethnicity & $17.0 \%$ & $14.0 \%$ & $17.3 \%$ \\
\hline \multicolumn{5}{|l|}{ Education } \\
\hline & Less than High School Diploma & $6.7 \%$ & $6.6 \%$ & $6.7 \%$ \\
\hline & High School Diploma or GED & $40.5 \%$ & $34.8 \%$ & $41.0 \%$ \\
\hline & Associate degree/technical degree & $14.2 \%$ & $14.9 \%$ & $14.1 \%$ \\
\hline & Undergraduate degree & $22.6 \%$ & $20.2 \%$ & $22.8 \%$ \\
\hline & Graduate Degree & $16.1 \%$ & $23.5 \%$ & $15.4 \%$ \\
\hline \multicolumn{5}{|l|}{ Party Affiliation } \\
\hline & Democrat & $43.9 \%$ & $51.1 \%$ & $43.1 \%$ \\
\hline & Republican & $32.1 \%$ & $30.1 \%$ & $32.3 \%$ \\
\hline & Independent/Other & $24.0 \%$ & $18.7 \%$ & $24.6 \%$ \\
\hline
\end{tabular}

Note: Estimates for the above race groups (White, Black or African American, and Asian) do not sum to totals because data are not presented for all races. Persons whose ethnicity is identified as Hispanic or Latino may be of any race. 
In comparison to the "average union member" based upon the CPS data, survey respondents' perception of union members were accurate representations on some measures and inaccurate on others. Survey respondents perceived the average union member to be overwhelmingly White males between the ages of 36 and 45 . The largest age group for union members is $45-54$ years of age (26.4), but the 35-44 group and the 54-64 group were also larger than the non-union groups. Thus, union members are generally older than non-union members. The union sample was $54.2 \%$ male, whereas the non-union was $51.6 \%$ male. As noted, the union sample was overwhelming White, but more diverse. Caucasians represented $76.4 \%$ of the union group but $78.2 \%$ of the non-union group. Within groups, Black employees are the most likely group to be unionized according to the BLS.

The perceived union member and the actual union member diverge on many of the remaining characteristics. For example, $61.1 \%$ of the students believe that union members' highest educational attainment is a high school diploma, whereas $59.3 \%$ of the union members in the sample have an Associate's degree or higher. Interestingly, union members are more 1.5 times more likely to have earned a graduate degree $(23.5 \%)$ in comparison to non-union members $(15.4 \%)$.

In regard to political affiliation and ideology, the most common perception of the union member is a moderate $(38.7 \%)$ Democrat $(58.6 \%)$. While the data suggest that the perception of political party affiliation (51.1\% Democrat) is fairly accurate, the political ideology is incorrect $(29.7 \%)$. In fact, union members are least likely to identify as Moderates. Most union members identify themselves as Liberals. In comparison, non-union members most closely identify as Conservatives (40.5\%).

While the perception is that union members work in the construction or manufacturing industries $(66.2 \%)$, approximately $50 \%$ of the union members work in the public sector with another $12 \%$ in education and health sectors. In reality, only $16 \%$ of union members are employed in construction or manufacturing industry. Therefore, there is a large perceptual gap regarding the work environment of union members.

A similar phenomenon existed in occupational perceptions. About $99 \%$ of respondents see union members as blue collar employees working in construction and maintenance $(44.8 \%)$ or production related occupations (35\%). On the other hand, about $6 \%$ of respondents perceive union members in management and professional related occupations. In contrast, roughly $42 \%$ of union members are in management and professional related occupations. While the $80 \%$ of respondents placed union members in construction, maintenance and production related occupations, in reality, only $15 \%$ are employed in these occupations.

While there is a large divergence of perception of union members and work environments, there is some convergence on social status and earnings. By far, union members and non-union members perceive themselves to be middle class. Union members (94.2\%) are more likely to hold this perception than non-union members ( $87.4 \%)$. This could be due to the $25 \%$ earnings premium for union members. The weekly reported mean earnings for non-union members was $\$ 802$ weekly $(\$ 41,700)$, whereas the union members reported weekly earnings was $\$ 1004(\$ 52,000)$. Based on available CPS data, non-union weekly earnings placed them in the 55th percentile. In comparison, union earnings are in the 66th percentile. While union members perceive themselves to be middle class, statistically, these earnings are borderline upper income.

Table 3 reports the responses to additional items. Fourteen percent of respondents believed that they had the same characteristics of union members. Given the large demographic overlap between the sample and union members, these groups actually have much more in common than respondents perceived. However, respondents may be using criteria other than those captured in this study. Future research should delve into the nature of the differences. Essentially, the question is: "Why do you see yourself as different?" 
Table 3. Similarity to prototype, negative perception of union member and intentions to join union.

\begin{tabular}{|c|c|c|}
\hline Item & Agreement & $\%$ \\
\hline \multirow[t]{3}{*}{ I believe union members are paid too much for their work } & Not Agree & 23.5 \\
\hline & Neither & 51.3 \\
\hline & Agree & 25.2 \\
\hline \multirow[t]{3}{*}{ I believe union members unnecessarily complain about their working conditions } & Not Agree & 24.5 \\
\hline & Neither & 25.8 \\
\hline & Agree & 49.7 \\
\hline \multirow[t]{3}{*}{ I believe union members are hard working } & Not Agree & 20.9 \\
\hline & Neither & 31.4 \\
\hline & Agree & 47.7 \\
\hline \multirow{3}{*}{ I have the same characteristics of my image of a union member } & Not Agree & 62.7 \\
\hline & Neither & 23.2 \\
\hline & Agree & 14.1 \\
\hline \multirow[t]{3}{*}{ Overall, I have a negative perception of union members } & Not Agree & 40.8 \\
\hline & Neither & 29.4 \\
\hline & Agree & 29.7 \\
\hline \multirow[t]{3}{*}{ Unions make it easier for employees to negotiate with management for better working conditions } & Not Agree & 14.4 \\
\hline & Neither & 18.6 \\
\hline & Agree & 67.0 \\
\hline \multirow[t]{3}{*}{ Unions represent the interests of their entire membership, not just the union leadership } & Not Agree & 32.0 \\
\hline & Neither & 19.6 \\
\hline & Agree & 48.4 \\
\hline \multirow[t]{3}{*}{ Unions tend to oppose management on improving production goals and work rules } & Not Agree & 23.5 \\
\hline & Neither & 32.4 \\
\hline & Agree & 44.1 \\
\hline \multirow[t]{3}{*}{ I approve of unions } & Not Agree & 26.8 \\
\hline & Neither & 41.2 \\
\hline & Agree & 32.0 \\
\hline \multirow[t]{3}{*}{ There was a time when unions were needed, but the need for them has now passed } & Not Agree & 25.5 \\
\hline & Neither & 27.5 \\
\hline & Agree & 47.0 \\
\hline \multirow[t]{3}{*}{ Unions attempt to influence political leaders in order to protect workers' rights } & Not Agree & 9.5 \\
\hline & Neither & 24.8 \\
\hline & Agree & 65.7 \\
\hline \multirow[t]{3}{*}{ Unions are good for the economy } & Not Agree & 31.0 \\
\hline & Neither & 49.7 \\
\hline & Agree & 19.3 \\
\hline \multirow[t]{3}{*}{ Unions negatively impact the performance of companies with unionized employees } & Not Agree & 26.8 \\
\hline & Neither & 34.3 \\
\hline & Agree & 38.9 \\
\hline \multirow[t]{3}{*}{ Unions hurt non-unionized employees in companies that are unionized } & Not Agree & 14.4 \\
\hline & Neither & 41.5 \\
\hline & Agree & 44.1 \\
\hline \multirow[t]{3}{*}{ If a union attempted to organize my workplace, I would vote for the union } & Not Agree & 48.7 \\
\hline & Neither & 30.7 \\
\hline & Agree & 20.6 \\
\hline \multirow[t]{3}{*}{ If I joined a company that had a union, I would join the union even if it was not required } & Not Agree & 45.1 \\
\hline & Neither & 34.0 \\
\hline & Agree & 20.9 \\
\hline \multirow[t]{3}{*}{ I would accept a job offer if I had to join a union as a condition for that job } & Not Agree & 33.3 \\
\hline & Neither & 33.7 \\
\hline & Agree & 33.0 \\
\hline \multirow[t]{3}{*}{ I would not take a job if I had to pay union fees, but did not have to join the union } & Not Agree & 26.8 \\
\hline & Neither & 26.1 \\
\hline & Agree & 47.1 \\
\hline \multirow[t]{3}{*}{ If I could receive the benefit of being in a union without joining the union, I would not join the union } & Not Agree & 18.0 \\
\hline & Neither & 22.2 \\
\hline & Agree & 59.8 \\
\hline
\end{tabular}


While the respondents did not perceive themselves as similar to union members, the majority did not have a negative perception of union members (70.2\%). Social identity theory (Tajfel 1972) would suggest that in-group members hold negative perceptions of group members. This apparently is not the case within this sample. One difference that might account is the perception of unions. Only $32 \%$ of respondents approved of unions. This suggests that outsiders perceive the union and its union members as distinct entities which may or may not be acting in concert.

In reference to being overpaid, most of them were indecisive (51.3\%). This is not surprising given that respondents completely misunderstood the environmental and occupational characteristics of union membership. The most common described industries and occupations were physically demanding occupations which could be considered stigmatized jobs (Ashforth et al. 2007). Respondents may have felt that individuals who perform stigmatized work functions should be compensated appropriately. This concept is supported by the approximately $50 \%$ of respondents who agreed that union members are hard working. As the new economy is one of knowledge, jobs that demand physical labor could be considered hard. However, the industrial and occupational environment of the perceived member is quite different than the reality. Even so, the union premium is approximately $25 \%$. This should be viewed with a jaundice eye. As previously noted, union members are $50 \%$ more likely to have a graduate degree. Thus, the increased premium may be justified as union members are more likely to hold an advanced degree which is associated with decreased levels of unemployment or increased job security. Future research should delve further into this differential.

While most believed that union members are hardworking and not overpaid, the majority of respondents (50\%) felt that union members overly complain. Respondents may have felt that if one is fairly compensated for labor, then he or she does not have a right to complain. Again, the mismatch of perceptions regarding the working environment of union members could greatly impact this perception.

As noted, only $32 \%$ of respondents approved of unions. Interestingly, there was far greater support for individual items than overall support. Future research should look more closely at the reasons and mismatch. This will provide union leadership with possible avenues to overcome declining union membership which stands at $10.7 \%$ overall and an anemic $6.4 \%$ in the private sector. Currently, private sector union density is below the one prior to passage of the National Labor Relations Act of 1935. Approximately $26 \%$ of respondents did not believe that union's time had passed and unions were an anachronism of a bygone era.

The majority of respondents $(67 \%)$ were in agreement that unions aid workers in negotiating with management for better working conditions. Respondents also felt that union leadership work for the good of all members (48.4\%). Approximately $66 \%$ of respondents support political unionism or attempting to influence elections and politicians for the good of union members. While outside members hold these views, union members and leaders have distinct differences on these views. For example, Gibney and colleagues (Gibney et al. 2012) found that union members frequently perceive the union to be a source of obstruction and withhold help. The concept of political unionism led to the split of the AFL-CIO and Change-to-Win (Masters et al. 2006).

The dichotomous results regarding union approval may be driven by a more personal and self-interested role. When responding to the item regarding union's opposition improving production and work rules, the largest group of respondents felt that unions oppose this. With increases in efficiency, organizations frequently reduce prices. Opposition to efficiency could result in higher prices hurting the purchasing power of respondents. In support of this view, respondents may have felt that unions negatively impact the performance of organizations. In a similar vein, only $14 \%$ of respondents disagreed with the idea that unions hurt non-union employees in a unionized environment.

Along these lines, only $19 \%$ of respondents felt that unions are good for the overall economy. In toto, it would seem that respondents believe that unions are good in theory but may negatively impact them through higher prices and the likelihood that they will be not be union employees. 
Union joining perceptions were also explored. Based upon the overall pattern of response and the generalizability of those responses, it does not seem that the decline in union density will reverse in the near future. Approximately $21 \%$ of respondents stated that they would support a union during an organizing campaign or voluntary join a union. On a more practical side, $33 \%$ of respondents were willing to take a job if it entailed joining the union. Interestingly, $47 \%$ of respondents would not be willing to take a job under an agency clause. Nearly $60 \%$ of respondents are willing to free-ride in a unionized environment.

\section{Discussion}

During the debate on the split of Change-to-Win coalition from the AFL-CIO, union leaders argued that the AFL-CIO should consider focusing on the image of unions in order to reverse the decline in union density. However, the results of this study suggest that this would not be enough. Non-members develop perceptions of union members and frequently do not see themselves as being similar to union members.

The overlapping identities are important as individuals will join (or not join) groups based upon social identity overlaps (Elsbach and Bhattacharya 2001). If individuals do not see themselves as having similar characteristics as union members, they may be less likely to join a union. Therefore, union leaders must not only be attentive to the perceptions regarding unions, but also to the way union members are perceived. The data suggest that these identities are not just demographic but also ideological and behavioral.

Based upon the selected characteristics, the statistically average union member was fairly similar to the respondents. However, the vast majority of respondents did not self-identify as being similar to this statistically average union member. This warrants future research. Union leaders need to work on both the branding and imaging of the union and the union member. The marketing campaign should be mutually reinforcing of one another.

Locals unions have to present the typical union member as an "everyman" who is part of the community (Israel 2014) by emphasizing this image with family and friends. Members who reinforce this image at home can positively influence non-members' perception of what it means to be a union member. The positive image of union members in turn might influence non-union members' attitude toward the union.

One method for portraying the union member, and possibly the union, in a more positive light is the use of the Internet. Unions need to get personal and utilize social media (Gibney et al. 2013; Israel 2014). It is not enough for union members to volunteer and act in a more positive light. This needs to be part of an orchestrated campaign, just as in the "union label" ads in the 1970s and 1980s which brought about public awareness to unions. While this focused on more instrumentality (better quality), the Millennials and Gen $\mathrm{Z}$ are now much more socially aware and influenced.

In all the positive joining intentions which excludes freeriding, respondents are not predisposed to joining the union. Altering the perceptions surrounding the member and union may have a positive impact on union organizing campaigns in the future. In this regard, union leadership should focus on negotiating volunteering in the agreements and/or support volunteerism in the union itself.

While the perception seems to be that unions are "pale, male and stale", union leadership should point out the welcoming environment and commitment to diversity that is evidenced by the more diverse membership. This push on membership should also include the diversity of occupations and industries that members support. A caveat here may be that the campaign may want to distance itself from the government given the low approval numbers.

The perception of adverse impact is another important area to overcome. Respondents' perceptions clearly suggest that unions are perceived to be good for union members and bad for everyone else. This is clearly an area that unions must work on to overcome the abysmal union density.

Unions are usually perceived as detrimental to the non-union employees, companies and the economy as a whole. In part, unions are seen as obstructionist. This perceived obstruction 
(Gibney et al. 2009, 2011, 2012) in turn reduces individuals' willingness to help the union, increases their exit intentions, and cognitive disassociate with the union. Union leadership should look for ways to counteract these three perceptions while simultaneously seeming to be relevant. This will be difficult because once a company, or person, is viewed as an ingroup or outgroup, overcoming the perception is often very difficult (Choi and Winterich 2013).

The extant literature on the declining union density offers wide ranging explanations for the weakening over the last few decades. These include changing demographics, the changing nature of jobs, governmental and human resource management substitution effects, and union organizing strategies themselves. However, individuals are more willing to join groups when there is an overlap between the individual's personal identity and group's identity and/or when an individual sees himself as having similar characteristics to his perception of existing group members. It is quite a defensible position that many of the benefits that employees in all organizations enjoy are due to mimetic isomorphism directly related to the efforts of the unions. Union affiliation was once a sought after affiliation which held great social esteem, but this is no longer the case. Different marketing techniques could be utilized to change these perceptions, but the union must first understand the roots of these perceptions.

The current research offers avenues for future research. First, this study should be replicated regarding different groups. Once verified that these beliefs are pervasive across different groups, union leadership should form focus groups to delve deeper into understanding the roots of these opinions. One of the biggest questions would be the transformation from being perceived as a major societal good to being a drag on the economy and companies. This will help formulate the marketing message and campaign.

Another area that must be addressed is the notion that unions are detrimental to non-union employees. Unions were once the stalwart of society which fought for the rights of all workers and not just for their own members. This perception has undergone a metamorphosis. In part, it may be due to management wining the message war, but events suggest a much deeper issue. For example, Volkswagen (VW) supported the bid of the United Autoworkers Union (UAW) to represent the workers at the Chattanooga, Tennessee plant. However, in a stinging blow to the union and management, employees voted against union representation by a 712-626 margin.

It is interesting that this anti-union sentiment exists prior to joining the workforce and the organizing campaign. This makes organizing campaigns much harder. Another area that must also be addressed is if this view is pervasive for all unions. It is highly plausible that people may like a union but dislike all unions in total akin to love an individual but hate society. This will have ramifications for coordination. Umbrella organizations such as the AFL-CIO and CTW which represent multiple unions may be the appropriate level for the campaigns. In addition, the face of these campaigns may have to be different than that of the leadership. The image of hard-hitting union boss who is out to win for her people is not the same image that will likely change the perception of others that we are all in this together. The adage that "a rising tide raises all boats" needs to be the new/old message again.

\section{Limitations}

The main limitation of this study is its cross-sectional nature. While college students were targeted for the aforementioned reasons, different generations may have much different perceptions. Future research should include diverse generations. In addition, respondents provided behavioral intentions. Although behavioral intentions are strongly, but not perfectly, correlated with actual behavior, respondents may intend to act in a certain manner, but actually act differently. Respondents may have limited knowledge of union members as evidenced by the difference between perceptions of members and reality. When exposed to actual data, perceptions may realign to reality. Finally, the area of the United States in which this survey was administered has been a traditional stronghold of union representation. This tradition of union representation may have influenced respondents' perceptions of members, pro-union attitudes and their union voting intentions. However, both universities recruit 
students nationally and internationally. Thus, while the universities are located in union strongholds, the respondents represent a diverse population.

\section{Conclusions}

There is a distinct gap between the perception of the union member and the statistically average union member. These differences could lead to lower success rates in union organizing campaigns in the future. While union leadership has acknowledged the need to change societal perceptions of unions, this may not go far enough. Unions must strive to create a better image of the union member as well as the union itself. This may mean taking a moral stance and sanctioning members when their behavior is detrimental to society. Teachers shooting heroin in school bathrooms, members burning down houses of worship or engaging in a host of other crimes should not be defended if unions want to increase union density.

Author Contributions: Conceptualization, R.G.; Data curation, R.G.; Formal analysis, M.M.; Writing—original draft, R.G., M.M. and O.A.; and Writing—review and editing, R.G., M.M., O.A. and T.A.

Funding: This research received no external funding.

Conflicts of Interest: The authors declare no conflict of interest.

\section{References}

Ashforth, Blake E., Glen E. Kreiner, Mark A. Clark, and Mel Fugate. 2007. Normalizing dirty work: Managerial tactics for countering occupational taint. Academy of Management Journal 50: 149-74. [CrossRef]

Barling, Julian, E. Kevin Kelloway, and Eric H. Bremermann. 1991. Preemployment predictors of union attitudes: The role of family socialization and work beliefs. Journal of Applied Psychology 76: 725-31. [CrossRef]

Barling, Julian, Clive Fullagar, and K. Kevin Kelloway. 1992. The Union and Its Members: A Psychological Approach. Oxford: Oxford University Press.

Bronfenbrenner, Kate. 1998. Reversing the tide of organizing decline: Lessons from the US experience. New Zealand, Journal of Industrial Relations 23: 21-34.

Butler, S. Brian, Patrick J. Bateman, Peter H. Gray, and E. Ilana Diamant. 2014. An attraction-selection-attrition theory of online community size and resilience. MIS Quarterly 38: 699-728. [CrossRef]

Cates, Steven V. 2014. The young and the restless: Why don't Millennials join unions? International Journal of Business \& Public Administration 11: 107-19.

Choi, Woo Jin, and Karen Page Winterich. 2013. Can brands move in from the outside? How moral identity enhances out-group brand attitudes. Journal of Marketing 77: 96-111. [CrossRef]

Cornwell, Benjamin, and Jill Ann Harrison. 2004. Union members and voluntary associations: Membership overlap as a case of organizational embeddedness. American Sociological Review 69: 862-81. [CrossRef]

Dark, Taylor E. 2000. Labor and the democratic party: A report on the 1998 elections. Journal of Labor Research 21: 627-40. [CrossRef]

Doucouliagos, Christos, and Patrice Laroche. 2003. What do unions do to productivity? A meta-Analysis. Industrial Relations: A Journal of Economy and Society 42: 650-91. [CrossRef]

Elsbach, Kimberly D., and C. B. Bhattacharya. 2001. Defining who you are by what you're not: Organizational disidentification and the National Rifle Association. Organization Science 12: 393-413. [CrossRef]

Festinger, Leon. 1954. A theory of social comparison processes. Human Relations 7: 117-40. [CrossRef]

Gibney, Ray, Thomas J. Zagenczyk, and Marick F. Masters. 2009. The negative aspects of social exchange: An introduction to POO. Group \& Organization Management 34: 665-97.

Gibney, Ray, Thomas J. Zagenczyk, J. Bryan Fuller, Kim Hester, and Turanay Caner. 2011. Exploring organizational obstruction and the expanded model of organizational identification. Journal of Applied Social Psychology 41: 1083-109. [CrossRef]

Gibney, Ray, Marick F. Masters, Thomas J. Zagenczyk, Thomas Amlie, and Stephen Brady. 2012. Union participation: A social exchange perspective. Journal of Management Policy and Practice 13: 35-49.

Gibney, Ray, Tom Zagenczyk, and Marick F. Masters. 2013. The Face (book) of unionism. International Journal of E-Politics (IJEP) 4: 1-12. [CrossRef] 
Hirsch, Barry T. 2004. What do unions do for economic performance? Journal of Labor Research 25: 415-55. [CrossRef] Hogg, Michael A., and Dominic Abrams. 2007. Intergroup behavior and social identity. In The Sage Handbook of Social Psychology: Concise Student Edition. London: SAGE, pp. 335-60.

Hogg, Michael A., and Sarah C. Hains. 1996. Intergroup relations and group solidarity: Effects of group identification and social beliefs on depersonalized attraction. Journal of Personality and Social Psychology 70: 295-309. [CrossRef]

Hogg, Michael A., and Deborah I. Terry. 2000. Social identity and self-categorization processes in organizational contexts. Academy of Management Review 25: 121-40. [CrossRef]

Israel, Josh. 2014. Five Ways Unions Are Trying to Get Their Mojo Back. Available online: https:/ /thinkprogress. org/five-ways-unions-are-trying-to-get-their-mojo-back-ff81afcc7784/ (accessed on 16 August 2018).

Leef, George. 2015. Unions Keep Losing Members-Can They Reinvent Themselves? Available online: https:/ / www.forbes.com/sites/georgeleef/2015/01/29/unions-keep-losing-members-can-they-reinventthemselves/\#3993ee3586ec (accessed on 16 August 2018).

Masters, Marick F., Ray Gibney, and Tom Zagenczyk. 2006. The AFL-CIO v. CTW: The competing visions, strategies, and structures. Journal of Labor Research 27: 473-504. [CrossRef]

Medoff, James L. 1987. The Public's Image of Labor and Labor's Response. Detroit College Law Review 1987: 609-36.

Park, Heejoon, Patrick P. McHugh, and Matthew M. Bodah. 2006. Revisiting general and specific union beliefs: The union-voting intentions of professionals. Industrial Relations: A Journal of Economy and Society 45: 270-89. [CrossRef]

Putnam, Robert D. 2001. Bowling Alone: The Collapse and Revival of American Community. New York: Simon and Schuster. Rosenfeld, Jake. 2014. What Unions No Longer Do. Cambridge: Harvard University Press.

Schneider, Benjamin, and D. Brent Smith. 2004. Personality and organizational culture. In Personality and Organizations. Mahwah: Lawrence Erlbaum Associates, Inc., pp. 347-69.

Tajfel, Henri. 1972. Social categorization. English translation of 'La categorisation sociale'. In Introduction a la Psychologie Sociale. Edited by de S. Moscovic. Paris: Laorusee, vol. 1, pp. 272-302.

Twenge, Jean M., W. Keith Campbell, and Elise C. Freeman. 2012. Generational differences in young adults' life goals, concern for others, and civic orientation, 1966-2009. Journal of Personality and Social Psychology 102: 1045-62. [CrossRef] [PubMed]

Youngblood, Stuart A., Angelo S. DeNisi, Julie L. Molleston, and William H. Mobley. 1984. The impact of work environment, instrumentality beliefs, perceived labor union image, and subjective norms on union voting intentions. Academy of Management Journal 27: 576-90. 